\title{
Kittiwake diets and chick production signal a 2008 regime shift in the Northeast Pacific
}

\author{
Scott A. Hatch* \\ US Geological Survey, Alaska Science Center, 4210 University Drive, Anchorage, Alaska 99508, USA
}

\begin{abstract}
I examined 2700 food samples collected from adult and nestling black-legged kittiwakes Rissa tridactyla from 1978 through 2011 on Middleton Island in the Gulf of Alaska. The kittiwake diet was composed chiefly of fish, but invertebrates were taken in appreciable quantities in April and May. Upon spring arrival at the colony, adult kittiwakes foraged regularly at night on vertically migrating mesopelagic prey - lanternfishes (Myctophidae), squids, crustaceans, and polychaetes - a behavior they largely discontinued by egg-laying. During incubation and chickrearing, food samples contained mostly ( 85\% by weight) Pacific sand lance Ammodytes hexapterus, capelin Mallotus villosus, Pacific herring Clupea pallasii, sablefish Anopoploma fimbria, krill (Euphausiidae), and juvenile salmon Onchorynchus gorboscha and O. keta. A salient finding over the longitudinal study was the emergence, twice, of capelin as a dominant forage species once in 2000 to 2003, and again in 2008 through 2011. Kittiwakes responded to capelin availability by producing markedly higher numbers of fledged young. The 2000 to 2003 event corresponded to a previously documented shift to cooler conditions in the NE Pacific, which apparently was relatively limited in magnitude or duration. The more recent transition appears stronger and may be more lasting. I submit that 2008 was an important turning point, marking a substantive reversal of warm conditions that began with the well-documented regime shift of 1977 . That interpretation is consistent with the existence of a $\sim 60 \mathrm{yr}$ cycle in ocean and atmospheric conditions in the North Pacific. All else being equal, it predicts the next 20 to $30 \mathrm{yr}$ will be favorable for species such as kittiwakes and Steller sea lions, which seemed to respond negatively to the 1977 to 2007 warm phase of the Pacific Decadal Oscillation.
\end{abstract}

KEY WORDS: Black-legged kittiwake · Steller sea lion · Forage fish · Capelin · Climate change • 60-year cycle $\cdot$ Pacific Decadal Oscillation $\cdot$ Prey relative occurrence

\section{INTRODUCTION}

Since recognition about 20 yr ago that a large-scale climatic change occurred in the North Pacific around 1977, the concept of periodic regime shifts has become an important organizing principle in marine ecology (Miller et al. 1994, Francis et al. 1998, McGowan et al. 1998, Jiao 2009). In simplified terms, a regime shift is a persistent change from warm to cool conditions, or the reverse, with biological responses that propagate through an ecosystem from plankton (Mackas et al. 1998, 2007, Batten \& Welch 2004) to fish (Beamish \& Bouillon 1993, Mantua et al. 1997, Mueter et al. 2007), birds (Piatt \& Anderson 1996, Irons et al. 2008, Gaston et al. 2009, Sydeman et al. 2009), and mammals (Alverson 1992, Pitcher 1990, Trites \& Donnelly 2003). Sensitized to the prospect and significance of regime shifts, marine scientists have scrutinized historical records for evidence of shifts prior to 1977 (Ware 1995, Mantua et al. 1997, Francis et al. 1998) and are ever on the lookout for contemporary shifts in physical and biological 
conditions. In the North Pacific, there is evidence that substantive shifts toward cooler conditions occurred in both 1989 (Ware 1995, Hare \& Mantua 2000, McFarlane et al. 2000) and 1999 (Greene 2002, Peterson \& Schwing 2003, Batten \& Welch 2004), but arguably no full-blown reversal (cold counterpart) of the warm phase established in 1977 has yet been detected.

Two upper trophic-level species that are widely monitored and that seemed to show strong responses to the 1977 regime shift are Steller sea lions Eumatopias jubatus and black-legged kittiwakes Rissa tridactyla. Over 2 decades from the late 1970s to late 1990s, the western stock of Steller sea lions (Gulf of Alaska through the Aleutian Islands and Bering Sea) declined about $70 \%$, and the species is currently listed as endangered in the region (www.adfg.alaska. gov/static/species/specialstatus/pdfs/stellersealion_ recovery.pdf). Likewise, the breeding productivity of Alaska kittiwakes declined after 1977 (Hatch et al. 1993, 2009), and numbers decreased sharply in some colonies (Fig. 1). Changes in both sea lions and kittiwakes are thought to be food related (Hatch et al. 1993, Merrick et al. 1997, Trites \& Donnelly 2003), and may in fact be closely linked. Both species likely depend as adults and/or during development on forage fish such as capelin, sand lance, and herring (see Table S1 in Supplement 1 at www.int-res.com/articles/ suppl/m477p271_supp.pdf for scientific names of most fish and invertebrates mentioned in text). Major changes in fish stocks after 1977 - declines in forage species and increases in demersal fish (e.g. pollock, halibut Hippoglossus stenolepis), salmon, and other species of lesser importance to birds and pinnipeds are documented (Anderson et al. 1997, Anderson \& Piatt 1999).

Kittiwakes are ubiquitous breeders in cold regions of the northern hemisphere and are undoubtedly the most widely monitored seabird species with respect to numbers and productivity (Frederiksen et al. 2005, 2007a, Hatch et al. 2009). Their confinement to surface foraging makes them highly sensitive to factors affecting the vertical distribution of prey. As open cliff-nesters, kittiwakes are easily studied in many respects, but diet information is less available because sampling entails lethal collection of birds or handling chicks and adults frequently to obtain regurgitated food items. Data on the summer diets of Alaska kittiwakes (Hatch et al. 2009) give the general impression of taxonomically stable food bases locally, with clear geographical differences. Birds in the Gulf of Alaska rely heavily on sand lance, capelin, and (especially in Prince William Sound)

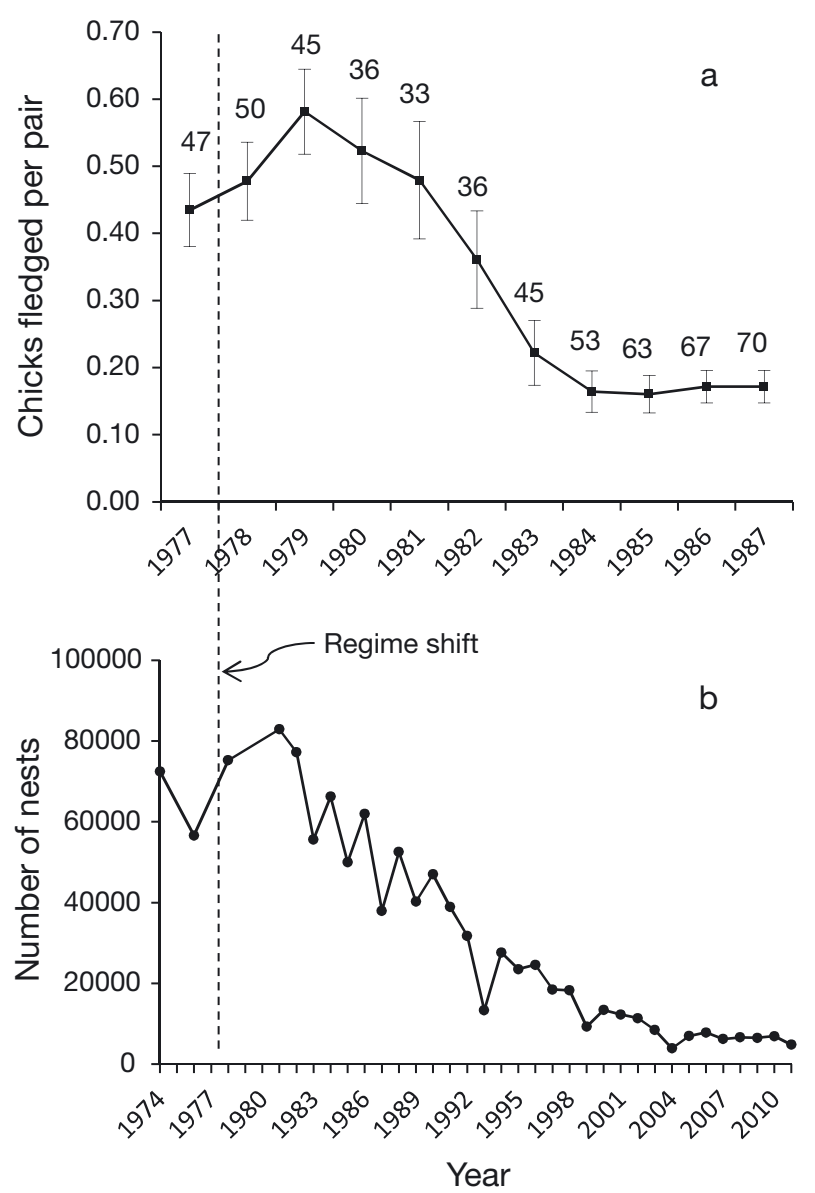

Fig. 1. Rissa tridactyla. Declines in kittiwake productivity and numbers following a 1977 regime shift in the North Pacific: (a) 5 yr running means $( \pm \mathrm{SE})$ of annual chick production in kittiwake colonies Alaska-wide (calculated from data in Hatch et al. 1993). Values above error bars are the numbers of measurements (colony-years) included in the means. (b) Population history of kittiwakes on Middleton Island, North-Central Gulf of Alaska

herring, whereas gadids (Arctic cod Boreogadus saida and juvenile walleye pollock) are prevalent at some colonies in the Bering and Chukchi seas. Most sampling reported to date is confined to the chickrearing period, and few published studies document kittiwake diets in more than a few years at any colony (but for the Pribilof Islands, Bering Sea, see Sinclair et al. 2008, Renner et al. 2012).

The aim of this paper is to report on long-running time series of diet samples and chick production in black-legged kittiwakes at an Alaskan colony and to highlight a clear transition that occurred in both parameters around 2008. I will argue that 2008 was an important threshold year, quite possibly marking a substantive reversal of the 1977 regime shift. 


\section{MATERIALS AND METHODS}

\section{Study area}

Middleton Island $\left(59.4^{\circ} \mathrm{N}, 146.3^{\circ} \mathrm{W}\right)$ is situated near the edge of the continental shelf in the northern Gulf of Alaska (Fig. 2). It lies squarely in the path of the Alaska Stream (Stabeno et al. 2004), and because of its distance from the mainland is probably influenced little by land morphology, freshwater runoff, and other factors operating locally nearer the coast (Mundy et al. 2010). Given its proximity to the shelf break, kittiwakes Rissa tridactyla breeding on Middleton have access to 2 distinct foraging habitats - a shallow ( 100 m) neritic zone, extending broadly to the east, west, and north of the island, and deep oceanic waters (200 to $4000 \mathrm{~m}$ ) over the continental slope and beyond. This situation is unusual for Gulf of Alaska colonies, but also exists at some breeding sites in the Aleutian Islands and Bering Sea. Middleton Island was an important haul-out and irregular breeding site for Steller sea lions until 1989, when an aggregation that numbered $\sim 1000$ to 3000 animals abruptly abandoned all use of the island. From 1990 through 2011 (summer seasons), sea lions have not returned in any appreciable numbers (NMFS Steller Sea Lion Count Database: www.afsc.noaa.gov/nmml/ alaska/sslhome/databases/adult.php; S. A. Hatch pers. obs.).

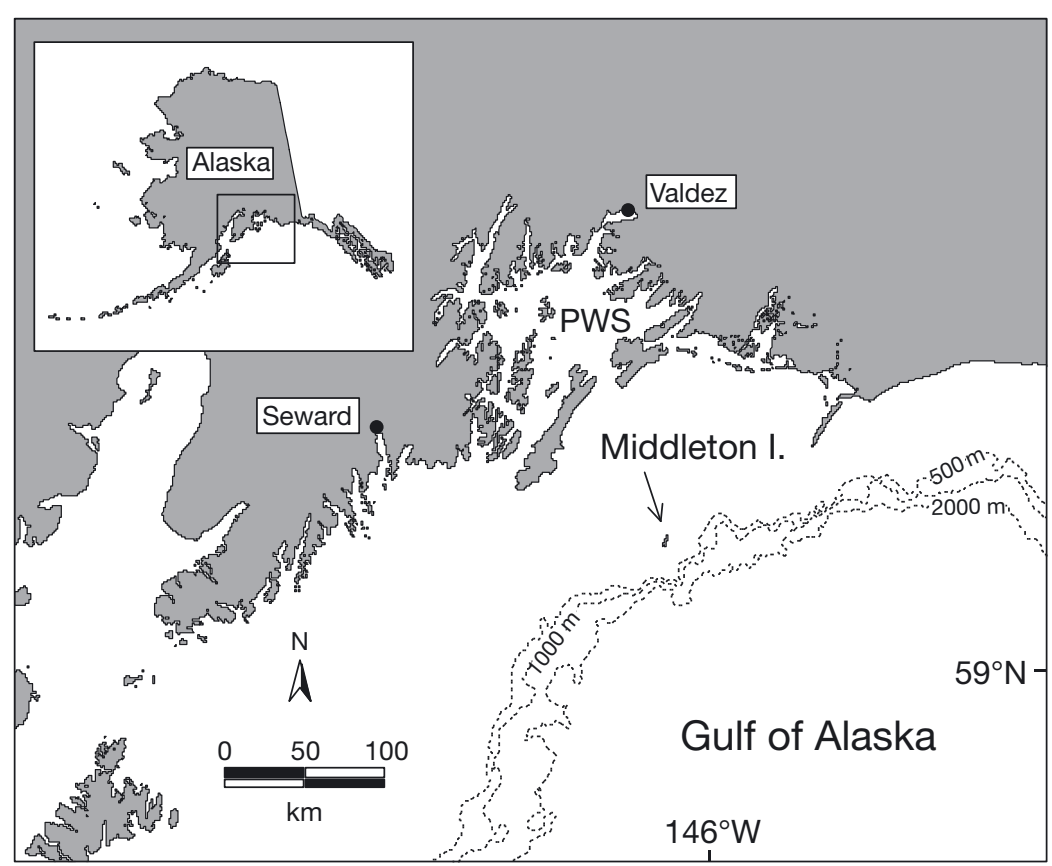

Fig. 2. Location of Middleton Island and its proximity to the continental shelf edge in the northern Gulf of Alaska. PWS: Prince William Sound

\section{Field collections}

Diet sampling of kittiwakes on Middleton spanned the period from 1978 to 2011, with large gaps in the early years but continuous observations since 1996. Chick production was measured in 1978 and annually since 1981. Food collections totaled 2703 samples, including 927 samples from adult kittiwakes and 1776 samples from chicks (Table 1). Apart from 75 adults collected offshore by shotgun in 1989 to 1990, all food samples were obtained as regurgitations from birds captured for measurements and banding at the colony. Regurgitated food samples consisted of slightly to moderately digested masses of recently ingested prey, i.e. kittiwakes do not cast pellets of fish bones, otoliths, and other indigestible prey parts, in contrast to some Larus gulls and cormorants (Phalacoracidae). Samples from the earlier years (through 1992) were preserved in alcohol or formaldehyde solution, whereas later collections were frozen for later sorting and identification in the laboratory.

The mean date of first egg-laying by kittiwakes on Middleton $( \pm \mathrm{SE})$ was 1 June $( \pm 2.3 \mathrm{~d}, \mathrm{n}=8 \mathrm{yr}$ between 1993 and 2000; S. A. Hatch unpubl. data), and casual observations by island residents (D. Baxter pers. comm.) indicate the birds typically reoccupy their nest sites in late March or early April. Therefore, samples collected in April and May correspond approximately to the prelaying period, while material from June through August corresponds to incubation and chick-rearing. To highlight changes that occur in spring, I further subdivided the samples into early prelaying (April) and late prelaying (May).

\section{Laboratory analysis and data summary}

In the laboratory, prey were identified to the lowest taxon possible, mostly under contract with K. Turco (Alaska's Spirit Speaks: Sound \& Science) in the years from 1994 through 2000. Material from 1978 and 2001 to 2011 was processed by me, whereas samples from 1989 to 1992 were analyzed by B. S. Fadely. In learning to distinguish and accurately identify prey types in kittiwake regurgitations, I was aided by having large numbers 
Table 1. Rissa tridactyla. Temporal distribution of diet samples from black-legged kittiwakes on Middleton Island, 1978 to 2011

\begin{tabular}{|c|c|c|c|c|c|c|c|c|c|c|c|c|}
\hline \multirow[t]{2}{*}{ Year } & \multirow{2}{*}{$\begin{array}{c}\text { Apr } \\
\text { Adults }\end{array}$} & \multirow{2}{*}{$\begin{array}{c}\text { May } \\
\text { Adults }\end{array}$} & \multirow{2}{*}{ Adults } & \multirow{2}{*}{ Jun - } & \multirow[b]{2}{*}{ Total } & \multirow{2}{*}{ Adults } & \multicolumn{2}{|c|}{ - Jul } & \multirow{2}{*}{ Adults } & \multicolumn{2}{|c|}{ - Aug } & \multirow{2}{*}{ Total } \\
\hline & & & & & & & Chicks & Total & & Chicks & Total & \\
\hline 1978 & & & & & & & 38 & 38 & & 2 & 2 & 40 \\
\hline 1989 & 2 & 2 & & & & 5 & & 5 & & & 0 & 9 \\
\hline 1990 & 17 & 7 & 18 & & 18 & 21 & 9 & 30 & & & 0 & 72 \\
\hline 1992 & & 1 & & & 0 & & & 0 & 3 & & 3 & 4 \\
\hline 1994 & 3 & & & & 0 & & & 0 & & & 0 & 3 \\
\hline 1996 & & 19 & & & 0 & & 37 & 37 & & 17 & 17 & 73 \\
\hline 1997 & & 4 & 4 & 3 & 7 & 3 & 107 & 110 & 1 & 35 & 36 & 157 \\
\hline 1998 & & 32 & 11 & 16 & 27 & 13 & 130 & 143 & 7 & 64 & 71 & 273 \\
\hline 1999 & & 11 & 11 & & 11 & 9 & 51 & 60 & 2 & 45 & 47 & 129 \\
\hline 2000 & 41 & 7 & 13 & 1 & 14 & 4 & 87 & 91 & & 29 & 29 & 182 \\
\hline 2001 & 10 & 19 & 7 & 23 & 30 & 10 & 321 & 331 & & 31 & 31 & 421 \\
\hline 2002 & 26 & 14 & 2 & 22 & 24 & 1 & 193 & 194 & & 22 & 22 & 280 \\
\hline 2003 & 4 & 22 & 24 & 3 & 27 & 22 & 15 & 37 & 5 & 2 & 7 & 97 \\
\hline 2004 & 9 & 8 & & 1 & 1 & 11 & 7 & 18 & & & 0 & 36 \\
\hline 2005 & 4 & 12 & 3 & & 3 & 5 & 10 & 15 & 1 & 2 & 3 & 37 \\
\hline 2006 & & 6 & 6 & 8 & 14 & & 100 & 100 & & 19 & 19 & 139 \\
\hline 2007 & 1 & 21 & 4 & & 4 & 13 & 3 & 16 & 1 & 3 & 4 & 46 \\
\hline 2008 & 44 & 10 & 4 & 2 & 6 & 2 & 40 & 42 & 2 & 13 & 15 & 117 \\
\hline 2009 & 36 & 21 & 16 & 2 & 18 & 22 & 27 & 49 & 2 & 7 & 9 & 133 \\
\hline 2010 & 39 & 51 & 39 & 34 & 73 & 27 & 128 & 155 & 4 & 36 & 40 & 358 \\
\hline 2011 & 32 & 14 & 3 & & 3 & 9 & 18 & 27 & 8 & 13 & 21 & 97 \\
\hline Total & 268 & 281 & 165 & 115 & 280 & 177 & 1321 & 1498 & 36 & 340 & 376 & 2703 \\
\hline
\end{tabular}

of prey samples from rhinoceros auklets Cerorhinca monocerata and tufted puffins Fratercula cirrhata collected on Middleton over the same span of years as the kittiwake studies (S. A. Hatch unpubl. data). The latter samples were whole (uningested) fish collected as bill-loads from chick-rearing auklets and puffins - ideal specimens from which to obtain diagnostic materials such as otoliths, parasphenoid bones and other skeletal elements, skin and scale samples, and other prey parts useful for species identification. Auklets and puffins reliably and exhaustively sampled the same forage fish community around Middleton as was used by foraging black-legged kittiwakes.

Thawed samples were weighed and sorted by prey types, each of which was further weighed and quantified by numbers of individual prey items. The latter I obtained by direct count (approximated in many cases) or, for the smallest invertebrate prey (krill and copepods), by extrapolation from prey mass using the average mass of individuals $(0.1 \mathrm{~g}$ for krill, $0.01 \mathrm{~g}$ for copepods). In 2 of the common fish prey (Pacific sand lance and Pacific herring), it was possible to distinguish young-of-the year (age-0) fish from older individuals readily by size.

Ideally, one would express diet composition in terms of percent biomass at the time of ingestion. That is not feasible for regurgitated food samples because it is difficult to separate fleshy material pre- cisely and also because of variable residence times and differential digestion in the gut (Duffy \& Jackson 1986, Barrett et al. 2007). The main comparative measure I used was the frequency of occurrence (i.e. presence-absence data) of each prey type, where the denominator was the sum of all prey type identifications in a given collection of samples. I call the measure 'relative occurrence' to distinguish it from a frequency of occurrence where the number of samples examined is used as the denominator. The difference between the 2 methods and the preference for relative occurrence over other possible measures of diet composition is addressed in Supplement 2 at www. int-res.com/articles/suppl/m477p271_supp.pdf. In calculating means across years, I used a 'mean of (annual) proportions,' as opposed to a 'pooled sample proportion' (see Supplement 2).

To test for age-related differences in diet (adult kittiwakes versus chicks), I applied Pearson chisquared tests to cross-tabulations of prey types and kittiwake age groups. Analyses were limited to months with chicks present (June to August) in years $(\mathrm{n}=16)$ when both age groups were sampled. An expected cell frequency $>1$ was required for inclusion in the chi-squared statistic. Because sample sizes for chicks and adults differed substantially among years, as did diet composition, I separated tests for years, then did a combined probabilities test 
(Sokal \& Rohlf 1995, p. 794-797) of the null hypothesis of no difference between chicks and adults.

Most food samples were taken from birds nesting on a tower at Middleton (Gill \& Hatch 2002), which has been used for in-depth studies of breeding seabirds since 1995. The tower was also the primary site for observations on chick production, as pairs could be monitored unobtrusively from inside the building through panes of 1-way mirror glass. Away from the tower, productivity was assessed by tallying nests built on a series of index plots in natural habitat (June) and counting the number of chicks surviving in the same plots late in the season (August).

Kittiwakes nesting on the tower were split into treatment groups - some were given supplemental food ad libitum throughout the breeding season, while the rest served as unfed controls (Gill \& Hatch 2002, S. A. Hatch unpubl. data). For present purposes, I considered only the productivity of unfed kittiwakes. Most food samples $(91 \%)$ included in the analysis were also obtained from unfed tower birds. Since 1998, the material used for supplemental feeding has been adult Atlantic capelin obtained from commercial fisheries in Newfoundland, Canada, and/or Iceland. I found that in all cases there was no difficulty distinguishing local capelin from Atlantic capelin, as the latter had distinctly larger bodies. I disqualified any sample containing supplemental Atlantic capelin.

To place the kittiwake diet analysis in the context of ocean regimes, I used graphical data for the Pacific Decadal Oscillation (PDO), which is openly available on the Internet but derives originally from the dataset supplied by N. Mantua (http://jisao.washington. edu/pdo/PDO.latest). I also considered a related index (Atmospheric Circulation Index, ACI) published by Klyashtorin $(1997,2001)$.

\section{RESULTS}

At least 40 species of fish and invertebrates occurred in kittiwake Rissa tridactyla regurgitations (Supplement 1). A comparison of analysis methods (Supplement 2) revealed that frequency of occurrence per prey type (relative occurrence) was the best-performing method of characterizing the diet, and that is primarily what is reported below.
Although chick samples outnumbered adults nearly 2:1 (Table 1), there was ample material from both groups and scant evidence that they should be treated separately. One of 16 chi-squared tests was significant $(1998, p=0.03), 1$ test yielded $p=0.064$, while 14 tests produced $p$-values between 0.126 and 0.816 . Given the number of tests performed, the 1998 result was quite possibly a Type II error (expected in 1 test among 20). The combined probability for 16 independent tests of the null hypothesis (no difference between chicks and adults) was $p=0.415$. I therefore pooled the samples from adults and chicks in all analyses to follow.

Fish dominated the diet overall, and 5 taxasand lance, capelin, herring, myctophids (lanternfish), and sablefish - made up the bulk of the fish prey (Fig. 3). There was, however, a marked seasonal transition. For several weeks following spring arrival, adult kittiwakes preyed heavily on myctophids and invertebrates, the latter consisting mainly of squid, 2 or more species of euphausiids (krill), the amphipod Paracallisoma alberti, and large $(\sim 9$ to $12 \mathrm{~cm})$ pelagic polychaetes. The use of myctophids and invertebrates declined through May, and by the main part of the breeding period (June to August) myctophids decreased to trace levels in the diet.
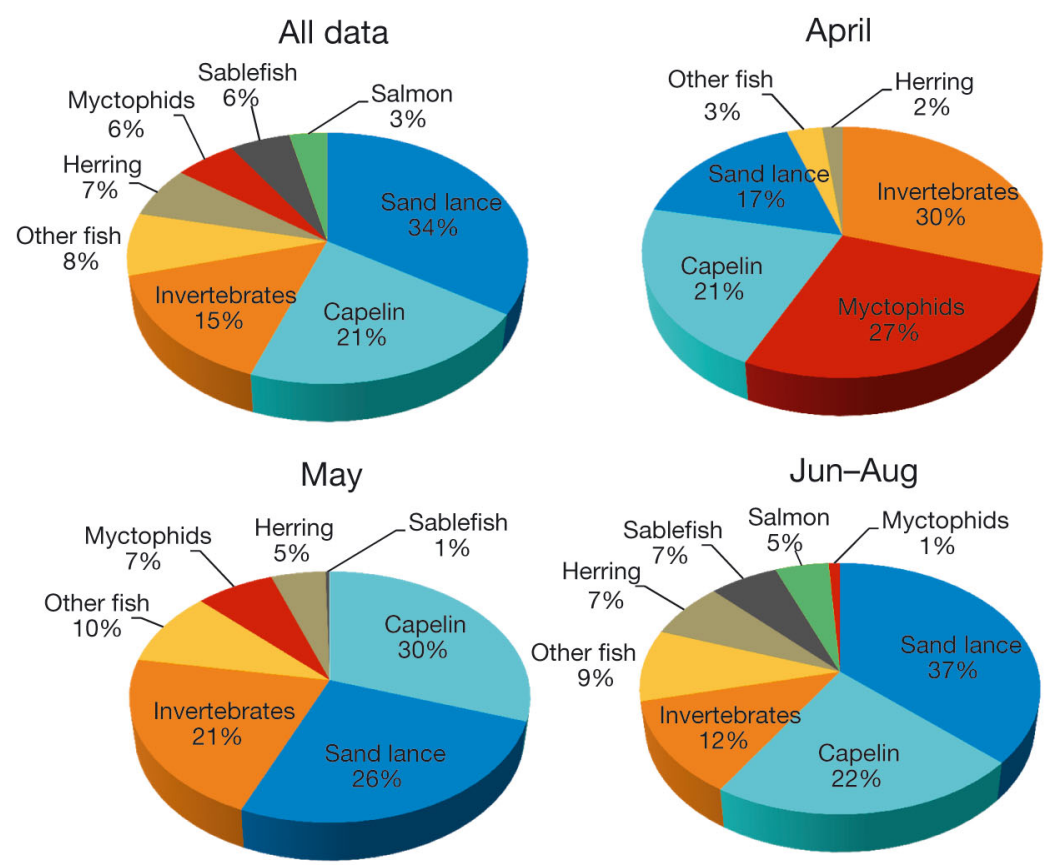

Fig. 3. Rissa tridactyla. Overall composition of kittiwake diet and composition during 3 stages of breeding on Middleton Island from 1978 to 2011. Sample sizes as listed in Table 1 


\section{Interannual variability and trends}

Over the course of the study, sand lance was the single most important prey species, followed by capelin. Capelin were scarce or absent in early years, but were prominent in 2 multi-year intervals after 1999, namely 2000 to 2003 and 2008 to 2011 (Fig. 4). In the latter interval, capelin dominated the diet even early in the season, when formerly either myctophids (April) or sand lance (May) had been the principal

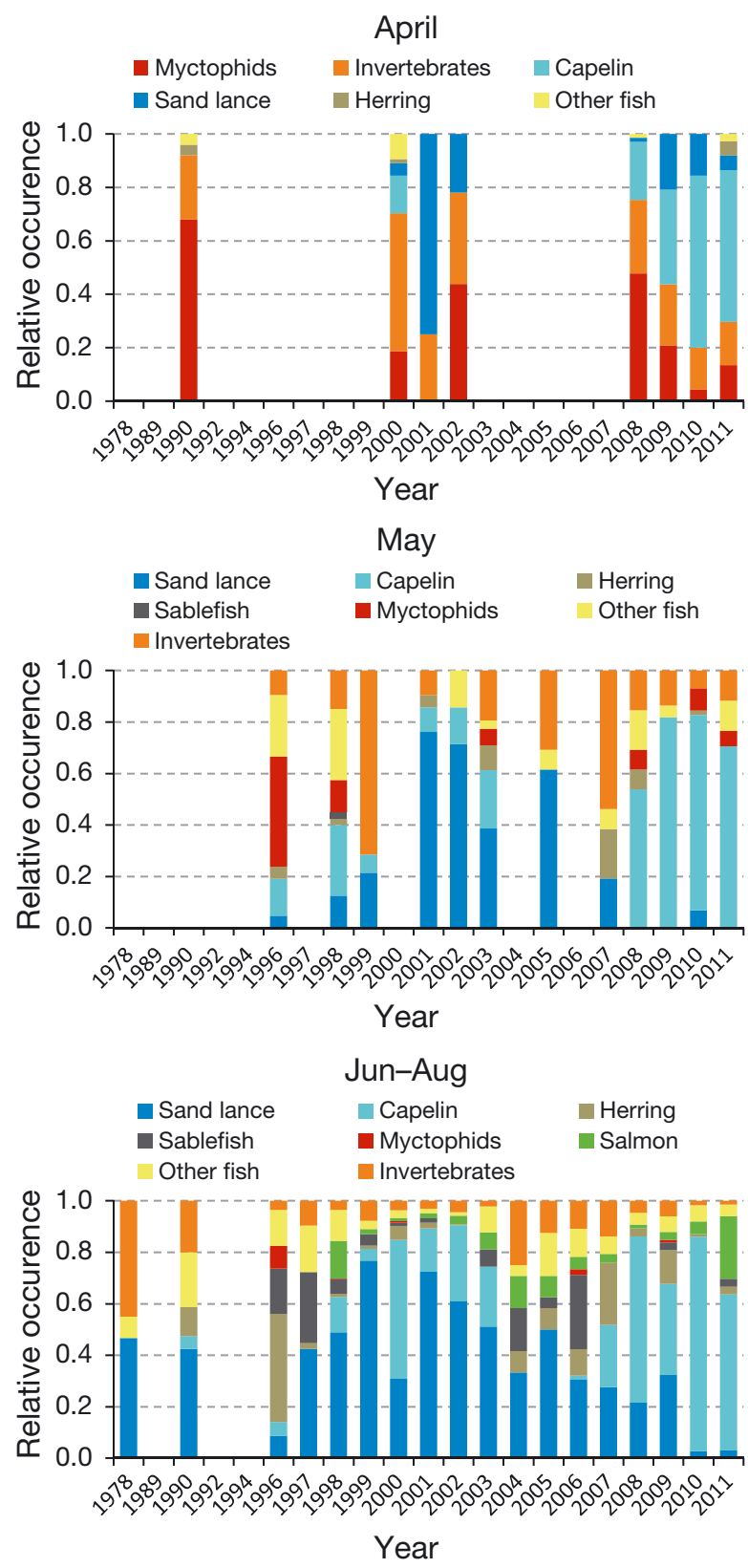

Fig. 4. Rissa tridactyla. Interannual variation in kittiwake diet composition at 3 stages of breeding on Middleton Island, 1978 to 2011. Sample sizes as listed in Table 1 fish prey. Charted individually, the complementary (i.e. roughly inverse) relation between relative occurrence of sand lance and capelin is evident $(\mathrm{r}=-0.54$, $\mathrm{p}=0.021$; Fig. 5). Other fish prey were important in the diet sporadically, e.g. herring in 1996 and 2007 and sablefish in 1996 to 1997 and 2006 (Fig. 4). Invertebrates (mainly euphausiids) contributed substantially to the chick diet in some years (e.g. 1978, 2004; Fig. 4).

\section{Prey age classes and reproductive status}

Among the sand lance and herring consumed, about 40 and $25 \%$, respectively, were first-year individuals, whether quantified by relative occurrence or percentage of biomass (Table 2). Juvenile herring appeared only during July and August, whereas age0 sand lance occurred in all months, increasing from around $10 \%$ of all sand lance in April to around $70 \%$ by August. The relative occurrence of first-year sand lance was variable among years (Fig. 6), and a pattern of strong age-0 classes followed by 1 or 2 yr dominated by older fish may have reflected the maturation and continued use by kittiwakes of strong year classes of sand lance produced, for example, in 2004, 2006, and 2009. The appearance occasionally of early post-larval sand lance $(\sim 30$ to $40 \mathrm{~mm}$; posi-

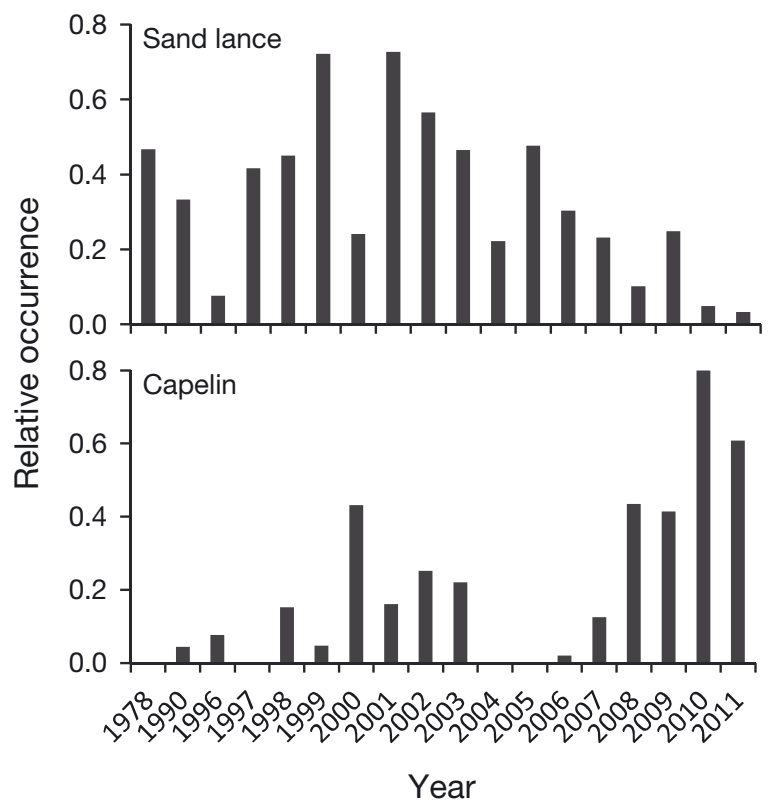

Fig. 5. Inverse relation between relative occurrences of Pacific sand lance and capelin in the summer diet of kittiwakes Rissa tridactyla on Middleton Island, 1978 to 2011. Data from all months combined; Pearson's $\mathrm{r}$ (sand lance versus capelin relative occurrences) $=-0.54, \mathrm{p}=0.021$ 
Table 2. First-year (age-0) sand lance and herring as percentages of each species' occurrence in the kittiwake Rissa tridactyla diet on Middleton Island

\begin{tabular}{|lccccc|}
\hline \multirow{2}{*}{ Month } & \multicolumn{2}{c}{ Sand lance } & & \multicolumn{2}{c|}{ Herring } \\
\cline { 6 - 6 } & $\begin{array}{c}\text { Relative } \\
\text { occurrence }\end{array}$ & $\begin{array}{c}\text { Biomass } \\
(\%)\end{array}$ & & $\begin{array}{c}\text { Relative } \\
\text { occurrence }\end{array}$ & $\begin{array}{c}\text { Biomass } \\
(\%)\end{array}$ \\
\hline Apr & 9.8 & 6.9 & 0.0 & 0.0 \\
May & 10.0 & 11.2 & 0.0 & 0.0 \\
Jun & 23.5 & 12.1 & & 0.0 & 0.0 \\
Jul & 45.0 & 45.0 & & 29.8 & 24.4 \\
Aug & 67.1 & 70.5 & 61.9 & 63.5 \\
All & 42.4 & 44.2 & 27.8 & 23.8 \\
\hline
\end{tabular}

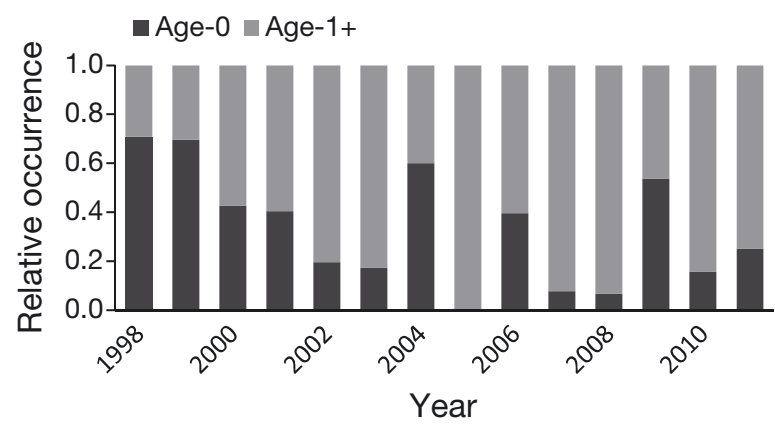

Fig. 6. Year-to-year changes in age composition of Pacific sand lance in the diet of black-legged kittiwakes Rissa tridactyla on Middleton Island, 1998 to 2011

tively identified by parasphenoid bones) in June and July suggested the likelihood of late winter spawning in the vicinity of Middleton Island.

Although beach spawning sites of capelin were not discovered on Middleton, the occurrence of gravid females in kittiwake diets and larval capelin in chick meals of rhinoceros auklets Cerorhinca monocerata

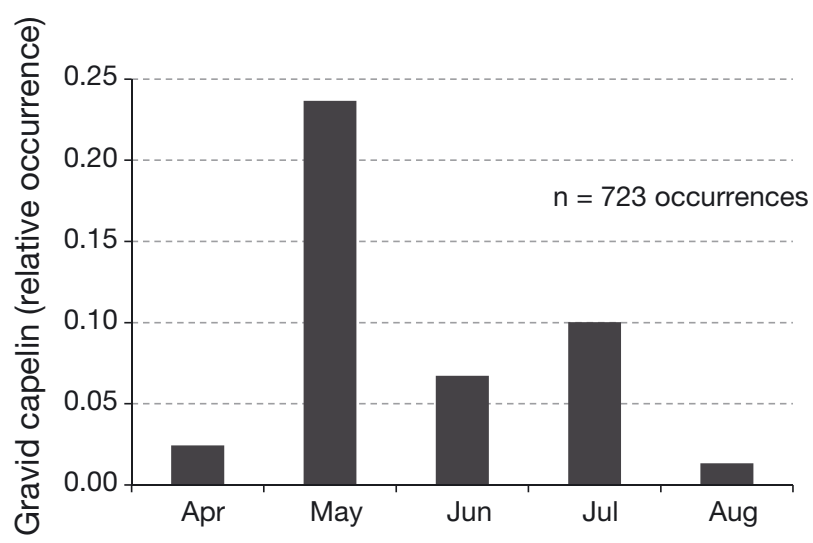

Fig. 7. Seasonal occurrence of gravid female capelin in kittiwake Rissa tridactyla diet samples from Middleton Island, 1978 to 2011
(S. A. Hatch unpubl. data) suggested the likelihood of local reproduction, apparently in deeper, offshore sites. The timing of egg-bearing females implies a peak of capelin spawning activity during May (Fig. 7). Years with the greatest numbers of gravid female capelin were $2000(\sim 30 \%)$ and $2009(\sim 26 \%)$.

Sablefish and salmon (including both pink and chum salmon) are species that rapidly outgrow the size range in which they are accessible to seabirds, and thus they occurred strictly as first-year fish in the kittiwake diet. Both species were taken seasonally during July and August, with a peak in sablefish occurrence preceding peak salmon occurrence by about a week (Fig. 8).

\section{Covariation of ocean temperature, capelin, and kittiwake chick production}

In the NE Pacific, the period from 1978 through 2007 was characterized by generally warm ocean conditions during summer, as indicated by the positive PDO index averaged over June, July, and August (Fig. 9). Within that period, a temporary shift to cooler conditions occurred from about 1999 to 2002, at which time capelin first appeared in appreciable quantities in the kittiwake diet at Middleton. Kittiwakes responded with markedly higher productivity in 2000 to 2002 (about 1 chick per breeding pair versus 0.2 chicks per pair on average in 20 prior years). From 2003 through 2007, sea surface temper-

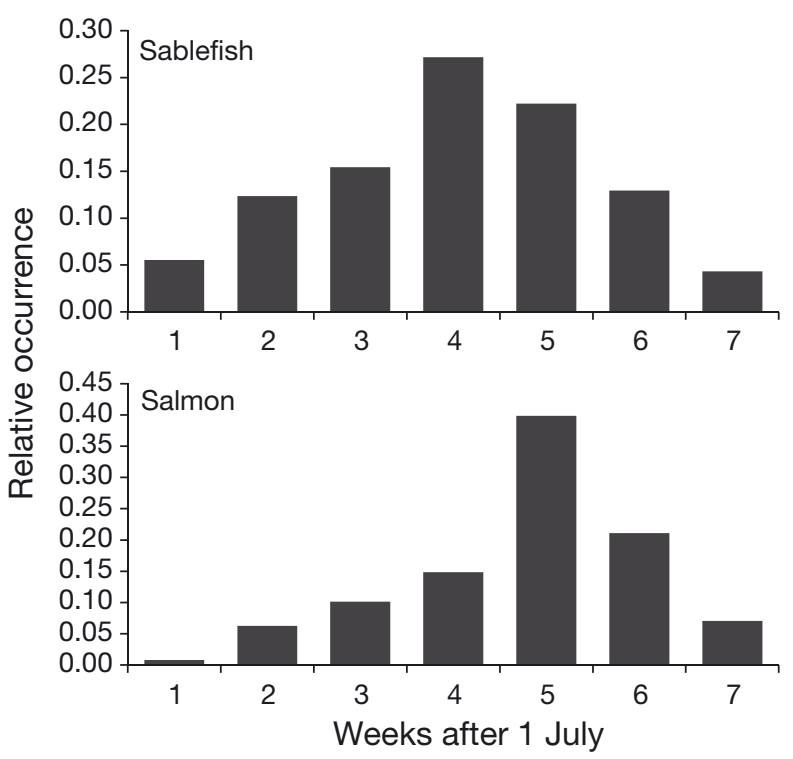

Fig. 8. Seasonality of sablefish and salmon in the diet of black-legged kittiwakes Rissa tridactyla on Middleton Island, 1978 to 2011 

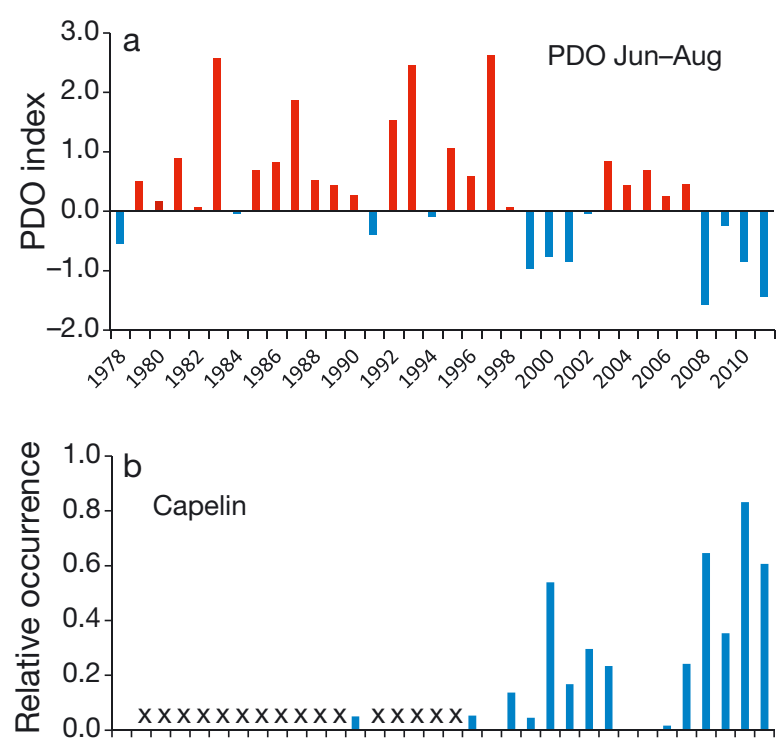

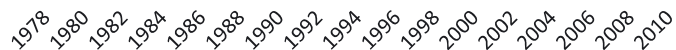

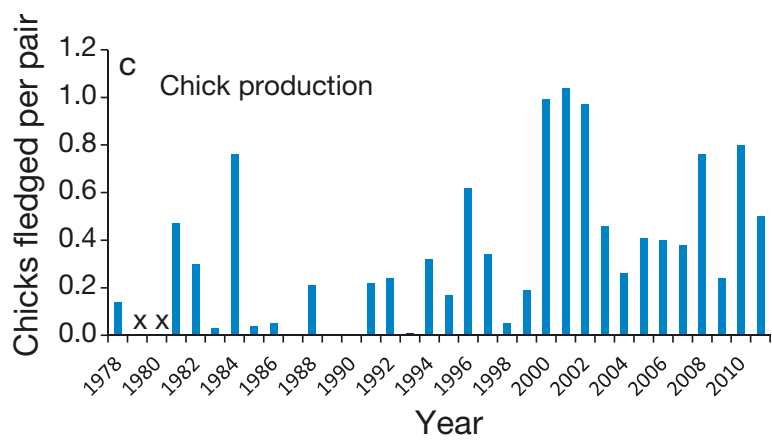

Fig. 9. (a) Relations among the Pacific Decadal Oscillation (PDO) index (June to August), (b) the relative occurrence of dietary capelin, and (c) annual chick production by kittiwakes Rissa tridactyla on Middleton Island, 1978 to 2011. Observations of chick production prior to 1991 were made away from the Middleton tower; subsequent data reflect the breeding performance of unfed birds at the tower. X: missing data

ature reverted to a warm state, capelin were scarce or absent in the kittiwake diet, and chick production declined to pre-2000 levels. Finally, 2008 marked the beginning of a second reversal of conditions - cool water, a resurgence of capelin, and improved breeding success among unfed kittiwakes on the Middleton tower. Simple correlation analysis confirmed the statistical significance and moderate explanatory power of the PDO-capelin-kittiwake relations ( $\mathrm{r}^{2}$ values from 0.304 to 0.367 ; Table 3 ).

Kittiwakes using natural cliffs as nesting habitat on Middleton are subject to greater harassment and predation by bald eagles Halieetus leucocephalus and glaucous-winged gulls Larus glaucescens than tower birds, and their breeding success was at or
Table 3. Pearson correlations among the Pacific Decadal Oscillation (PDO) index (June to August), relative occurrence of dietary capelin, and kittiwake Rissa tridactyla chick production on Middleton Island over $32 \mathrm{yr}$, between 1978 and 2011

\begin{tabular}{|llcc|}
\hline \multirow{2}{*}{ Variable } & Statistic & \multicolumn{2}{c}{ Variable } \\
\cline { 3 - 4 } & & Chick & Capelin \\
production & in diet \\
\hline Capelin in diet & Pearson's r & 0.551 & - \\
& $\mathrm{p}$ (2-tailed) & 0.018 & - \\
& $\mathrm{n}$ (yr) & 18 & - \\
PDO (Jun-Aug) & Pearson's r & -0.505 & -0.606 \\
& $\mathrm{p}$ (2-tailed) & 0.003 & 0.008 \\
& $\mathrm{n}$ (yr) & 32 & 18 \\
\hline
\end{tabular}

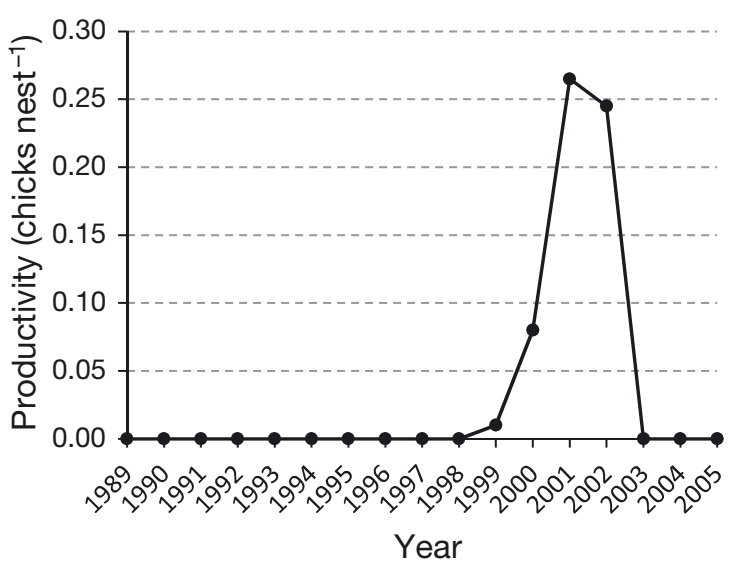

Fig. 10. Rissa tridactyla. Productivity of kittiwakes breeding in natural cliff habitat on Middleton Island, 1989 to 2005. A positive response to cooling surface water and dietary capelin was evident in 2000 to 2002

near zero in the decade from 1989 to 1999. Against that background, the birds' response to the cooling episode and capelin abundance in 2000 to 2002 was conspicuous (Fig. 10). The syndrome of abject failure returned subsequently, however, and in recent years the few birds remaining on natural cliffs have effectively ceased to function as a viable colony (i.e. no chick production from 2006 to 2011).

\section{DISCUSSION}

Far from being a fixed aspect of the local environment, the forage fish community around Middleton Island, as displayed in kittiwake Rissa tridactyla diet composition, changed markedly in the years from 1978 through 2011. Some of the local diversity of fish prey reflects the island's location on the outermost shelf, where myctophids and other mesopelagic prey 
are available to kittiwakes foraging at night. Middleton's proximity to the demersal spawning grounds of sablefish (>300 m on the continental slope; Sigler et al. 2001) accounts for that species' appearance in appreciable numbers during some years - juvenile sablefish are epipelagic, moving inshore and growing rapidly there during their first year of life (Kendall \& Matarese 1987). Likewise, the outmigration and early development of juvenile pink and chum salmon from spawning streams and hatcheries in SE Alaska and Prince William Sound matches well the chick-rearing period of kittiwakes on Middleton (Willette et al. 2001). Neither salmon species is commonly reported in Alaskan seabird diets.

Studies that examine concurrently the foods of adult and nestling seabirds often find dietary differences between the 2 (Barrett et al. 2007). While that was not the case here, no firm conclusion was possible as most of the regurgitations obtained from adults during chick-rearing probably represented food intended for chicks. The use of pelagic prey (myctophids, squids, polychaetes, crustaceans) by adult kittiwakes in spring did not extend into the chickrearing period, presumably because forage fish became available closer to the island later in the season.

The most salient finding was that the kittiwake diet shifted conspicuously to capelin when surrounding waters turned relatively cold. The apparent timing of capelin availability has advanced in recent years, with kittiwakes now feeding heavily on capelin upon their arrival at the colony in April, foregoing to a large extent the pelagic foraging they practiced in earlier years. Ecologically, capelin are considered to be a 'cold water' species whose distribution is sensitive to small changes in ocean temperature (Rose 2005, Hollowed et al. 2007). Large movements of capelin among offshore areas in the NW Atlantic have coincided with anomalous cold-water events (Frank et al. 1996); thus, the availability and use of capelin by seabirds in the region is strongly coupled with oceanographic conditions (Carscadden et al. 2002, Davoren et al. 2012). In Alaska, a signature change in fish and shellfish communities following the 1977 regime shift was the virtual disappearance of shrimp and capelin in nearshore trawl surveys (Anderson et al. 1997, Anderson \& Piatt 1999). Whether the change in capelin stocks was manifested primarily in overall abundance, distributional shifts, or both is poorly understood (Brown 2002, Doyle et al. 2002, Arimitsu et al. 2008). Certainly, pockets of local capelin abundance (as reflected in seabird diets) persisted in the 1980s (Hatch \& Sanger 1992), but limited information on diets prior to 1977 suggests greater use of capelin during the preceding cold period in Alaska (Piatt \& Anderson 1996).

At many locations in Alaska, Pacific sand lance has been the primary forage species of kittiwakes and other seabirds in the last 30 yr (Hatch \& Sanger 1992, Willson et al. 1999, Hatch et al. 2009). It remains to be seen whether a shift from sand lance to capelindominated summer diets, as documented here for Middleton Island, has already transpired or will occur at many of the same locations. Without independent knowledge of species' abundances in the water column, it is not possible to say whether the emergence of capelin as the dominant forage species at Middleton reflects a decline of sand lance, a superabundance of capelin, or both. The dynamics of sand lance and capelin in Alaska may be analogous to the regular fluctuations of sardines Sardinops sagax, anchovies Engraulis spp., and herrings Clupea spp. in other ocean regions, with sand lance (sardines) dominating in warm conditions and capelin (anchovies or herring) holding sway in times of cooler climate (Baumgartner et al. 1992, Kawasaki 1992, Chavez et al. 2003).

Following the well-studied and widely acknowledged regime shift of the late 1970s, analysis of physical and biological time series led some researchers to conclude that substantive shifts (warm to cold) occurred in both 1989 (Ware 1995, Hare \& Mantua 2000) and 1998 to 1999 (Minobe 2002, Chavez et al. 2003, Peterson \& Schwing 2003, Batten \& Welch 2004). The 'reality' or importance of both of those purported change points has been debated (McFarlane et al. 2000, Greene 2002, Bond et al. 2003), and depending on one's temporal frame of interest and criteria for regime change, there will inevitably be 'false positives' identified with sufficient hindsight (Schwing \& Moore 2000, Rodionov \& Overland 2005). The 1989 and 1999 events, for example, were probably driven to some degree by the La Niña conditions that prevailed in 1988 to 1989 and 1998 to 2001, respectively (National Weather Service, www. cpc.ncep.noaa.gov/products/analysis_monitoring/ ensostuff/ensoyears.shtml). It is possible the proposed 2008 regime change will also prove to be ephemeral-strong La Niña conditions prevailed during many months in 2007 to 2011 (National Weather Service, loc. cit.), and as yet there is little in the kittiwake responses on Middleton Island to distinguish between 2000 to 2003 and 2008 to 2011 (Fig. 9). However, for reasons depicted graphically (Fig. 11) and discussed below, it seems likely that the latest shift to cold water, capelin abundance, and improved kittiwake performance will be a more 

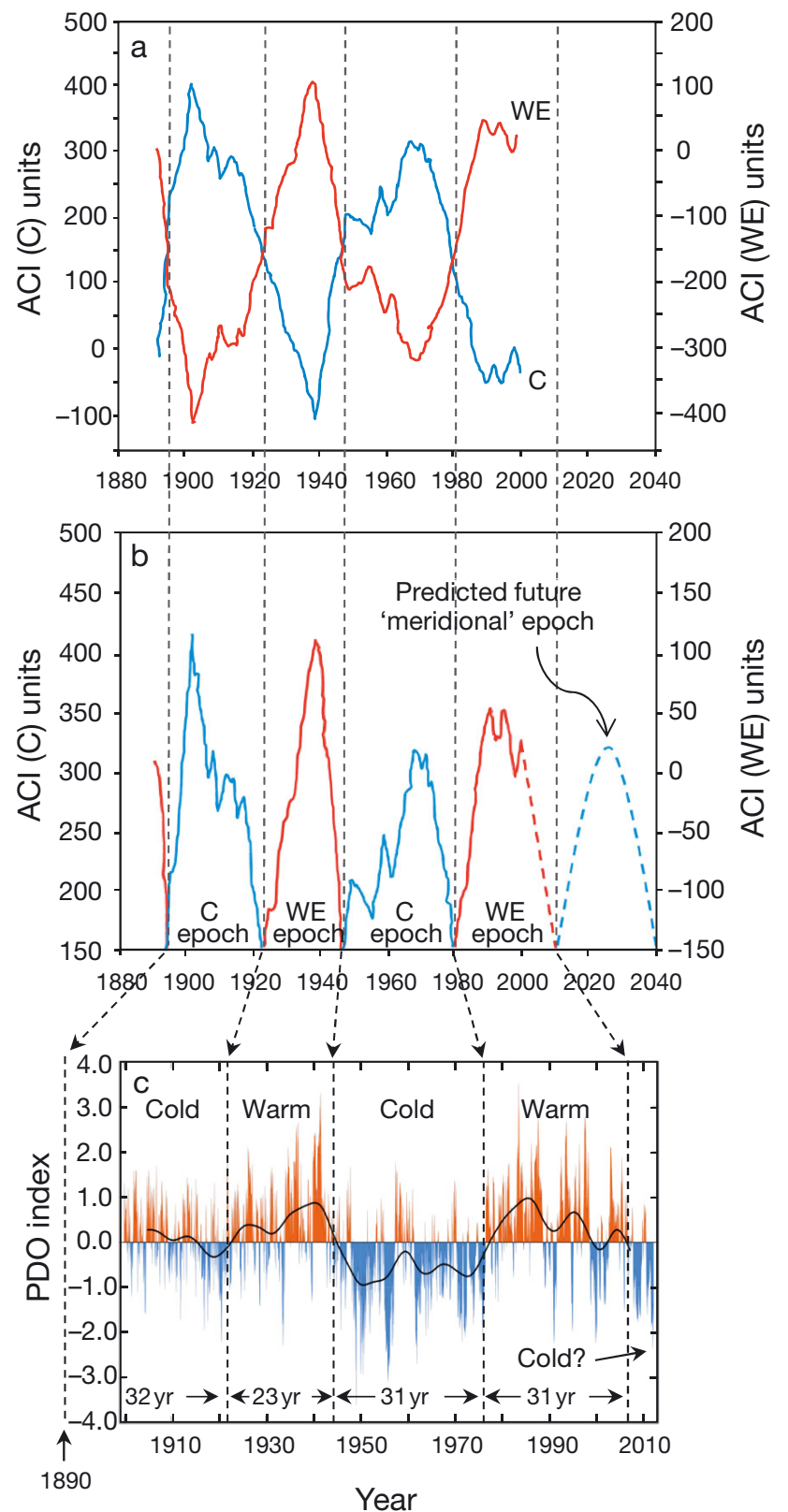

Fig. 11. (a,b) Measured atmospheric circulation index (ACI) and model of air movements over the North Atlantic and Europe (redrawn from Klyashtorin 2001) suggests a close connection between phases of ocean warming and cooling and synoptic patterns of air circulation in the northern hemisphere (see 'Discussion') with 2 competing modes of circulationmeridional (C) and latitudinal (combined west and east, denoted WE). (c) Pacific Decadal Oscillation (PDO) indices 1900 to present (http://en.wikipedia.org/wiki/Pacific_decadal _oscillation, based on data from N. Mantua: http://jisao. washington.edu/pdo/PDO.latest), showing 3 previously identified shifts in the PDO ( 1921, 1945, and 1977), a prior regime shift ( 1890) documented by Minobe (1997), and a presumptive shift from warm to cold conditions in the northeast Pacific around 2008 (curve: multi-year smoothed curve of PDO index). Dashed arrows highlight the close correspondence between change points identified in the ACI and PDO models robust and lasting change to the ecosystem than that which occurred in either 1989 or 2000. Specifically, there is a basis for viewing the 2008 change point as a true counterpart - a reversal - of the warm phase begun in 1977 .

In the literature pertaining to climate fluctuations and associated patterns of species' abundances, there are many references to what is commonly called a (or 'the') '60-year cycle' (e.g. Baumgartner et al. 1992, Klyashtorin 1997, Zhen-Shan \& Xian 2007). While $60 \mathrm{yr}$ is a convenient period to use for modeling purposes (Loehle \& Scafetta 2011, Zwolinski \& Demer 2012), examination of empirical data of various types and durations leads different authors to speak of a '50-year cycle' (Chavez et al. 2003), a 'quasi 60-year cycle' (Mazzarella \& Scafetta 2011), a '50-70 year cycle' (Minobe 1997, 1999, Mantua \& Hare 2002, Klyashtorin et al. 2009), a '50-79 year cycle' (Humlum et al. 2011), or a '50-75 year cycle' (Ware 1995). Given decidedly noisy signals, long periodicities relative to human lives and datasets, possible lag times, and limited or no understanding of mechanisms, it remains to be shown to what extent such reports are describing either the same or multiple, unconnected phenomena. Without question, the amount and quality of relevant data have increased dramatically in recent decades, and the pace of discovery will continue to accelerate. In the PDO time series (Fig. 11), a mid1940s change point and the late-1970s change point seem well-defined, giving a bounded cold period of 31 yr. In the ensuing warm phase, we saw the previously noted jumps to negative PDO values ( 1989 and 1999 to 2002), but neither condition persisted. A more lasting transition to cold conditions in 2008 would close a $\sim 31$ yr warm phase and complete a full cycle (cold-warm-cold) that began around 1944. Under that scenario, a regime shift in 2008 was predicted. Time will tell whether the model of a $\sim 60 \mathrm{yr}$ cycle holds up in this instance.

Klyashtorin $(1997,2001)$ and Klyashtorin et al. (2009) find strong correlations between global commercial fish production and climate indices, including a global temperature anomaly computed for instrumental data collected since $\sim 1850$ and another synoptic indicator called the ACI. The ACI summarizes annual patterns of atmospheric pressure and air mass transfer over the Atlantic-Eurasian region. Three basic types of circulation - meridional (denoted C), western (W), and eastern (E) - are recognized, and the index further categorizes circulation into 2 competing modes: meridional (C) and latitudinal (combined W and E, denoted WE or 'zonal'). The 2 modes are strictly complementary (inversely related) 
because their measures are obtained in such a way that they sum to zero (Fig. 11a). The points in time at which one mode or the other becomes dominant define so-called 'epochs' of air mass circulation (denoted C and WE epochs, respectively) the durations of which have averaged about $30 \mathrm{yr}$ over the past $120 \mathrm{yr}$ (Fig. 11b). The change points between epochs correspond closely to change points recognized in the PDO index (Mantua \& Hare 2002, Minobe 1997; Fig. 11b,c). The ACI model anticipated a phase change to occur in 2008 and predicts a cold (WE) epoch to persist for $\sim 30 \mathrm{yr}$ thereafter (Fig. 11b). Russian and Australian geophysicists (Sidorenkov \& Wilson 2009, Sidorenkov et al. 2010) find close correspondence, with lag times, between global temperature anomalies since 1900, the ACI, and cyclic gravitational characteristics of the solar system. The Russian models deserve careful consideration and further testing, because they offer predictive capability relevant to wildlife conservation and fisheries management and suggest physical mechanisms related to $60 \mathrm{yr}$ cycles.

If 2008 proves to be a definitive change point in a $\sim 60 \mathrm{yr}$ cycle, then the next couple of decades should be good ones for sea lions and kittiwakes in Alaska. We should see kittiwakes on Middleton Island continue to have improved breeding success, and their numbers should increase (subject to availability of suitable nesting habitat, which is declining due to post-earthquake successional change). We should expect to find sea lions rebuilding their numbers, including a recolonization of Middleton Island as a breeding and/or haul-out site. While the change may not be good for Alaskan salmon, stocks in the Pacific Northwest should respond favorably - there is evidence (Francis et al. 1998) that salmon production is inversely affected by warm and cold phases in the California Current and Alaska Current systems.

The concept of natural climate cycles - including, besides the mentioned $60 \mathrm{yr}$ periodicity, purported cycles of 20 yr (Minobe 1999, Mantua \& Hare 2002, Loehle \& Scafetta 2011), other relatively high-frequency harmonics (Ware 1995, Zhen-Shan \& Xian 2007, Scafetta 2012), and even centenarial and millennial scale oscillations (Humlum et al. 2011) - is controversial, because it impinges on the debate about greenhouse gas effects and anthropogenic global warming. One school of thought (IPCC 2007) maintains that warming since $\sim 1970$ is primarily attributable to human activity, while another (ZhenShan \& Xian 2007, Klyashtorin et al. 2009, Scafetta 2010, 2012, Humlum et al. 2011, Loehle \& Scafetta 2011) argues that natural cycles of climate variation are equally or more important. A third point of view is that the worst effects of human-caused warming are still to come as methane release from melting permafrost and other amplifying feedbacks cause runaway increases in global temperature and sea level (Lawrence \& Slater 2005, Hansen \& Sato 2012). Fortunately, these competing views make specific and opposing predictions for global temperature measurements in coming decades, and the crux of the issue should be settled within 10 to $20 \mathrm{yr}$.

The traction that long-term datasets have given us toward understanding ocean dynamics is a strong affirmation of the historical-descriptive approach advocated by Francis \& Hare (1994). Going forward, it will be important to systematically monitor as many components of ecosystems as is feasible, and especially to maintain the continuity of extended time series already established for indicators such as sea lions, kittiwakes, Pacific salmon, and sardines. It is safe to say that commercially important species such as salmon and sardines will be monitored de facto, as will charismatic and legally supported species such as Steller sea lions. The contribution that seabird monitoring can make during this crucial time of hypothesis-testing and decision-making is at present limited by access to original data that should be synthesized. Useful approaches will include statistical methods that combine and extract information from multiple, concurrent datasets (e.g. Sydeman et al. 2001, Frederiksen et al. 2007b, Wells et al. 2008). Thus, I would emphasize the need for world seabird professionals to distill and capture all past and future results from seabird monitoring in shared databases designed for the purpose and served on the Internet (e.g. World Seabird Trophic Studies Database, Pacific [World] Seabird Monitoring Database; http://seabirds.net).

Acknowledgements. Many volunteer and student field workers assisted in the collection of kittiwake diet samples and in productivity monitoring. I particularly thank the several camp leaders who supervised Middleton Island field work in 2 or more years: V. A. Gill, C. Sterne, N. A. Bargmann, A. M. Ramey, J. Kotzerka, T. van Nus, and L. Agdere. Special thanks also to B. S. Fadely for his contributions to kittiwake diet studies in 1989 to 1992. This project would not have been possible without unwavering support from the US Geological Survey. Any use of trade names is for descriptive purposes only and does not imply endorsement by the US Government.

\section{LITERATURE CITED}

Alverson DL (1992) A review of commercial fisheries and the Steller sea lion (Eumetopias jubatus): the conflict arena. Rev Aquat Sci 6:203-256 
Anderson PJ, Piatt JF (1999) Community reorganization in the Gulf of Alaska following ocean climate regime shift. Mar Ecol Prog Ser 189:117-123

Anderson PJ, Blackburn JE, Johnson BA (1997) Declines of forage species in the Gulf of Alaska, 1972-1995, as an indicator of regime shift. In: Forage fishes in marine ecosystems. Report No. 97-01, Alaska Sea Grant College Program, University of Alaska, Fairbanks, AK, p 531-543

> Arimitsu ML, Piatt JF, Litzow MA, Abookire AA, Romano MD, Robards MD (2008) Distribution and spawning dynamics of capelin (Mallotus villosus) in Glacier Bay, Alaska: a cold water refugium. Fish Oceanogr 17:137-146

> Barrett RT, Camphuysen CJ, Anker-Nilssen T, Chardine JW and others (2007) Diet studies of seabirds: a review and recommendations. ICES J Mar Sci 64:1675-1691

Batten SD, Welch DW (2004) Changes in oceanic zooplankton populations in the north-east Pacific associated with the possible climatic regime of 1998/1999. Deep-Sea Res II 51:863-873

Baumgartner TR, Soutar A, Ferreira-Bartrina V (1992) Reconstruction of the history of Pacific sardine and northern anchovy populations over the past two millennia from sediments of the Santa Barbara Basin, California. CCOFI Rep 33:24-40

> Beamish RJ, Bouillon DR (1993) Pacific salmon production trends in relation to climate. Can J Fish Aquat Sci 50: 1002-1016

> Bond NA, Overland JE, Spillane M, Stabeno P (2003) Recent shifts in the state of the North Pacific. Geophys Res Lett 30:2183, doi:10.1029/2003GL018597

> Brown ED (2002) Life history, distribution, and size structure of Pacific capelin in Prince William Sound and the northern Gulf of Alaska. ICES J Mar Sci 59:983-996

Carscadden JE, Montevecchi WA, Davoren GK, Nakashima BS (2002) Trophic relationships among capelin (Mallotus villosus) and seabirds in a changing ecosystem. ICES J Mar Sci 59:1027-1033

> Chavez FP, Ryan J, Lluch-Cota SE, Ñiquen CM (2003) From anchovies to sardines and back: multidecadal change in the Pacific Ocean. Science 299:217-221

> Davoren GK, Penton P, Burke C, Montevecchi WA (2012) Water temperature and timing of capelin spawning determine seabird diets. ICES J Mar Sci 69:1234-1241

> Doyle MJ, Busby MS, Duffy-Anderson JT, Picquelle SJ, Matarese AC (2002) Early life history of capelin (Mallotus villosus) in the northwest Gulf of Alaska: a historical perspective based on larval collections, October 1977March 1979. ICES J Mar Sci 59:997-1005

Duffy DC, Jackson S (1986) Diet studies of seabirds: a review of methods. Colon Waterbirds 9:1-17

> Francis RC, Hare SR (1994) Decadal-scale regime shifts in the large marine ecosystems of the north-east Pacific: a case for historical science. Fish Oceanogr 3:279-291

Francis RC, Hare SR, Hollowed AB, Wooster WS (1998) Effects of interdecadal climate variability on the oceanic ecosystems of the NE Pacific. Fish Oceanogr 7:1-21

Frank KT, Carscadden JE, Simon JE (1996) Recent excursions of capelin (Mallotus villosus) to the Scotian Shelf and Flemish Cap during anomalous hydrographic conditions. Can J Fish Aquat Sci 53:1473-1486

> Frederiksen M, Harris MP, Wanless S (2005) Inter-population variation in demographic parameters: a neglected subject? Oikos 111:209-214

> Frederiksen M, Edwards M, Mavor RA, Wanless S (2007a) Regional and annual variation in black-legged kittiwake breeding productivity is related to sea surface temperature. Mar Ecol Prog Ser 350:137-143

- Frederiksen M, Mavor RA, Wanless S (2007b) Seabirds as environmental indicators: the advantages of combining data sets. Mar Ecol Prog Ser 352:205-211

Gaston AJ, Bertram DF, Boyne AW, Chardine JW and others (2009) Changes in Canadian seabird populations and ecology since 1970 in relation to changes in oceanography and food webs. Environ Rev 17:267-286

Gill VA, Hatch SA (2002) Components of productivity in black-legged kittiwakes Rissa tridactyla: response to supplemental feeding. J Avian Biol 33:113-126

Greene K (2002) Coastal cool-down. Science 295:1823

Hansen JE, Sato M (2012) Paleoclimate implications for human-made climate change. In: Berger A, Mesinger F, Sijacki D (eds) Climate change: inferences from paleoclimate and regional aspects. Springer, Vienna, p 21-48

- Hare SR, Mantua NJ (2000) Empirical evidence for North Pacific regime shifts in 1977 and 1989. Prog Oceanogr 47: 103-145

Hatch SA, Sanger GA (1992) Puffins as samplers of juvenile pollock and other forage fish in the Gulf of Alaska. Mar Ecol Prog Ser 80:1-14

Hatch SA, Byrd GV, Irons DB, Hunt GL (1993) Status and ecology of kittiwakes (Rissa tridactyla and $R$. brevirostris) in the North Pacific. In: Vermeer K, Briggs KT, Morgan $\mathrm{KH}$, Siegel-Causey D (eds) The status, ecology, and conservation of marine birds of the North Pacific. Special Publication, Canadian Wildlife Service, Ottawa, p 140-153

Hatch SA, Robertson GJ, Baird PA (2009) Black-legged kittiwake (Rissa tridactyla). In: Poole A (ed) The birds of North America, No. 92. Available online at: http://bna. birds.cornell.edu/bna/species/092 (accessed 27 Feb 2013)

Hollowed AB, Wilson CD, Stabeno PJ, Salo SA (2007) Effect of ocean conditions on the cross-shelf distribution of walleye pollock (Theragra chalcogramma) and capelin (Mallotus villosus). Fish Oceanogr 16:142-154

Humlum O, Solheim JE, Stordahl K (2011) Identifying natural contributions to late Holocene climate change. Global Planet Change 79:145-156

IPCC (Intergovernmental Panel on Climate Change) (2007) Climate change 2007: the IPCC fourth assessment report (AR 4). IPCC, Cambridge University Press, Cambridge

> Irons DB, Anker-Nilssen T, Gaston AJ, Byrd GV and others (2008) Fluctuations in circumpolar seabird populations linked to climate oscillations. Glob Change Biol 14: 1455-1463

Jiao Y (2009) Regime shift in marine ecosystems and implications for fisheries management, a review. Rev Fish Biol Fish 19:177-191

Kawasaki T (1992) Mechanisms governing fluctuations in pelagic fish populations. S Afr J Mar Sci 12:873-879

Kendall AW, Matarese AC (1987) Biology of eggs, larvae, and epipelagic juveniles of sablefish, Anoplopoma fimbria, in relation to their potential use in management. Mar Fish Rev 49:1-13

Klyashtorin LB (1997) Global climate cycles and Pacific forage fish stock fluctuations. In: Forage fishes in marine ecosystems. Report No. 97-01, Alaska Sea Grant College Program, University of Alaska, Fairbanks, AK, p 545-557

Klyashtorin LB (2001) Climate change and long-term fluctuations of commercial catches: the possibility of forecasting. Fisheries Technical Paper No. 410, United Nations Food and Agriculture Organization, Rome 
Klyashtorin LB, Borisov V, Lyubushin A (2009) Cyclic changes of climate and major commercial stocks of the Barents Sea. Mar Biol Res 5:4-17

Lawrence DM, Slater AG (2005) A projection of severe nearsurface permafrost degradation during the 21st century. Geophys Res Lett 32:L24401, doi:10.1029/2005GL025080

Loehle C, Scafetta N (2011) Climate change attribution using empirical decomposition of climate data. Open Atmos Sci J 5:74-86

> Mackas DL, Goldblatt R, Lewis AG (1998) Interdecadal variation in developmental timing of Neocalanus plumchrus populations at Ocean Station P in the subarctic North Pacific. Can J Fish Aquat Sci 55:1878-1893

Mackas DL, Batten S, Trudel M (2007) Effects on zooplankton of a warmer ocean: recent evidence from the northeast Pacific. Prog Oceanogr 75:223-252

Mantua NJ, Hare SR (2002) The Pacific decadal oscillation. J Oceanogr 58:35-44

- Mantua NJ, Hare SR, Zhang Y, Wallace JM, Francis RC (1997) A Pacific interdecadal climate oscillation with impacts on salmon production. Bull Am Meteorol Soc 78: 1069-1079

- Mazzarella A, Scafetta N (2011) Evidences for a quasi 60year North Atlantic Oscillation since 1700 and its meaning for global climate change. Theor Appl Climatol 107: 599-609

> McFarlane GA, King JR, Beamish RJ (2000) Have there been recent changes in climate? Ask the fish. Prog Oceanogr 47:147-169

> McGowan JA, Cayan DR, Dorman LM (1998) Climate-ocean variability and ecosystem response in the Northeast Pacific. Science 281:210-217

> Merrick RL, Chumbley MK, Byrd GV (1997) Diet diversity of Steller sea lions (Eumetopias jubatus) and their population decline in Alaska: a potential relationship. Can J Fish Aquat Sci 54:1342-1348

- Miller AJ, Cayan DR, Barnett TP, Graham NE, Oberhuber JM (1994) The 1976-77 climate shift of the Pacific Ocean. Oceanography 7:21-26

Minobe S (1997) A 50-70 year climatic oscillation over the North Pacific and North America. Geophys Res Lett 24: 683-686

> Minobe S (1999) Resonance in bidecadal and pentadecadal climate oscillations over the North Pacific: role in climatic regime shifts. Geophys Res Lett 26:855-858

> Minobe S (2002) Interannual to interdecadal changes in the Bering Sea and concurrent 1998/99 changes over the North Pacific. Prog Oceanogr 55:45-64

Mueter FJ, Boldt JL, Megrey BA, Peterman RM (2007) Recruitment and survival of northeast Pacific Ocean fish stocks: temporal trends, covariation, and regime shifts. Can J Fish Aquat Sci 64:911-927

Mundy PR, Allen DM, Boldt JL, Bond NA and others (2010) Alaska Current. In: McKinnell SM, Dagg MJ (eds) Marine ecosystems of the North Pacific Ocean, 2003-2008. PICES Special Publication No. 4, Sydney, BC, p 143-194

Peterson WT, Schwing FB (2003) A new climate regime in northeast Pacific ecosystems. Geophys Res Lett 30:1896, doi:10.1029/2003GL017528

Piatt JF, Anderson PJ (1996) Response of common murres to the Exxon Valdez oil spill and long-term changes in the Gulf of Alaska marine ecosystem. In: Rice SD, Spies RB, Wolf DA, Wright BA (eds) Proceedings of the Exxon Valdez oil spill symposium. American Fisheries Society Symposium, Bethesda, MD, p 720-737
Pitcher KW (1990) Major decline in number of harbor seals, Phoca vitulina richardsi, on Tugidak Island, Gulf of Alaska. Mar Mamm Sci 6:121-134

Renner HM, Mueter F, Drummond BA, Warzybok JA, Sinclair EH (2012) Patterns of change in diets of two piscivorous seabird species during 35 years in the Pribilof Islands. Deep-Sea Res II 65-70:273-291

Rodionov S, Overland JE (2005) Application of a sequential regime shift detection method to the Bering Sea ecosystem. ICES J Mar Sci 62:328-332

Rose GA (2005) Capelin (Mallotus villosus) distribution and climate: a sea 'canary' for marine ecosystem change. ICES J Mar Sci 62:1524-1530

Scafetta N (2010) Empirical evidence for a celestial origin of the climate oscillations and its implications. J Atmos Sol Terr Phys 72:951-970

Scafetta N (2012) Testing an astronomically based decadalscale empirical harmonic climate model versus the IPCC (2007) general circulation climate models. J Atmos Sol Terr Phys 80:124-137

Schwing F, Moore C (2000) A year without summer for California, or a harbinger of a climate shift? Eos Trans AGU 81:301-305

Sidorenkov N, Wilson IRG (2009) The decadal fluctuations in the earth's rotation and in climate characteristics. In: Soffel M, Capitaine N (eds) Proceedings of the 'Journees 2008 Systemes de reference spatio-temporels.' Lohrmann-Observatorium and Observatoire de Paris, Vienna, p 174-177

Sidorenkov N, Wilson I, Khlystov A (2010) Decadal variations in geophysical processes and asymmetries in the solar motion about the solar system's epicentre. Geophys Res Abstr 12:EGU2010-9559

Sigler MF, Rutecki TL, Courtney DL, Karinen JF, Yang MS (2001) Young of the year sablefish abundance, growth, and diet in the Gulf of Alaska. Alsk Fish Res Bull 8:57-70

Sinclair EH, Vlietstra LS, Johnson DS, Zeppelin TK and others (2008) Patterns in prey use among fur seals and seabirds in the Pribilof Islands. Deep-Sea Res II 55: 1897-1918

Sokal RR, Rohlf FJ (1995) Biometry, 3rd edn. W. H. Freeman \& Company, New York, NY

Stabeno PJ, Bond NA, Hermann AJ, Kachel NB, Mordy CW, Overland JE (2004) Meteorology and oceanography of the northern Gulf of Alaska. Cont Shelf Res 24:859-897

Sydeman WJ, Hester MM, Thayer JA, Gress F, Martin P, Buffa J (2001) Climate change, reproductive performance and diet composition of marine birds in the southern California Current system, 1969-1997. Prog Oceanogr 49:309-329

Sydeman WJ, Mills KL, Santora JA, Thompson SA and others (2009) Seabirds and climate in the California Current-a synthesis of change. CCOFI Rep 50:82-104

Trites AW, Donnelly CP (2003) The decline of Steller sea lions Eumetopias jubatus in Alaska: a review of the nutritional stress hypothesis. Mammal Rev 33:3-28

Ware DM (1995) A century and a half of change in the climate of the NE Pacific. Fish Oceanogr 4:267-277

Wells BK, Field JC, Thayer JA, Grimes CB and others (2008) Untangling the relationships among climate, prey and top predators in an ocean ecosystem. Mar Ecol Prog Ser 364:15-29

Willette TM, Cooney RT, Patrick V, Mason DM, Thomas GL, Scheel D (2001) Ecological processes influencing mortality of juvenile pink salmon (Oncorhynchus gorbuscha) 
in Prince William Sound, Alaska. Fish Oceanogr 10(Suppl 1):14-41

Willson MF, Armstrong RH, Robards MD, Piatt JF (1999) Sand lance as cornerstone prey for predator populations. In: Robards MD, MF Willson, Armstrong RH, Piatt JF (eds) Sand lance: a review of biology and predator relations and annotated bibliography. Research Paper PNWRP-521, US Forest Service, Pacific Northwest Research

Editorial responsibility: Yves Cherel, Villiers-en-Bois, France
Station, Portland, OR, p 17-44

Zhen-Shan L, Xian S (2007) Multi-scale analysis of global temperature changes and trend of a drop in temperature in the next 20 years. Meteorol Atmos Phys 95:115-121

Zwolinski JP, Demer DA (2012) A cold oceanographic regime with high exploitation rates in the northeast Pacific forecasts a collapse of the sardine stock. Proc Natl Acad Sci USA 109:4175-4180

Submitted: July 2, 2012; Accepted: November 6, 2012

Proofs received from author(s): February 27, 2013 